\title{
"Here on the Verge of Town ... I Am Myself" : Selective Western Exceptionalism in the Work of Six Contemporary Idaho Writers
}

\section{Susan H. Swetnam}

\section{(2) OpenEdition Journals}

Electronic version

URL: https://journals.openedition.org/ejas/9365

DOI: 10.4000/ejas.9365

ISSN: 1991-9336

\section{Publisher}

European Association for American Studies

\section{Electronic reference}

Susan H. Swetnam, " "Here on the Verge of Town ... I Am Myself" : Selective Western Exceptionalism in the Work of Six Contemporary Idaho Writers", European journal of American studies [Online], 6-3 | 2011, document 4, Online since 28 September 2011, connection on 08 July 2021. URL: http:// journals.openedition.org/ejas/9365 ; DOI: https://doi.org/10.4000/ejas.9365

This text was automatically generated on 8 July 2021 .

Creative Commons License 


\title{
"Here on the Verge of Town ... I Am Myself" : Selective Western Exceptionalism in the Work of Six Contemporary Idaho Writers
}

\author{
Susan H. Swetnam
}

\section{Introduction}

1 Between the hundredth meridian and the crest of the Sierra/Cascade mountain ranges, Wallace Stegner suggested in a 1975 interview with the national magazine Holiday, "something abides that is different, separate, uniquely itself" (49). This notion of the exceptionalism of the American West has a long history, fostered in Jefferson agrarianism; in Frederick Jackson Turner's famous hypothesis that the frontier's open land offered safety-valve-style opportunities for the nation's disadvantaged; and in the popular imagination of early twentieth century travelers, whose mind-set Richard Athearn characterizes thus: "Out under that big sky they sensed the presence of subtle qualities that suggested the existence of old-time American values" including an open welcoming spirit, "dignified courtesy and absence of servility," and "the courtliness of men who were at ease with the world, who were independent without being surly" (75-76). Stegner himself maintained that, despite commercialism and "huckstering," "there is a lot of the West where both illimitable freedom and perfect sanctuary may be found" (49).

2 Even in the twenty-first century West, such highly-generalized exceptionalist claims about the salutary effects of the West on human character, interactions, and progress are widely held. As a university faculty member in the Intermountain West, I routinely hear fellow Idahoans (especially the native-born) extol the region's supposed extraordinary friendliness relative to the rest of America (the habit of waving to strangers from one's pick-up truck is frequently evoked), its guardianship of old-time 
family values ("your family will always support you out here, unlike in other places today," one of my students wrote), and its boundless opportunities for anyone who is willing to work. Our local newspaper, the Idaho State Journal, frequently voices exceptionalist booster rhetoric about wide-open business opportunities and local strength of character reminiscent of nineteenth-century frontier journalism.

Those who make such claims are, of course, out of touch with more than forty years of "New Western" discourse about the region's history and contemporary circumstances. Patricia Nelson Limerick, Donald Worster, David Wrobel, and a host of other scholars have written definitively about the West's "legacy of conquest," its colonial status relative to the rest of America, its deliberate myth-making that has never much corresponded with social realities. The West's boom and bust economy has been extensively documented, as has the region's vexed history of water management. Violence and exploitation-especially toward ethnic minorities and women, but also toward economically marginalized Anglo settlers and the poor today-has been chronicled, as has the prevalence of domestic violence, divorce, and abandonment. Poverty and its attendant problems, scholars have demonstrated, are as endemic in the West as anywhere else.

Revisionist literary texts, films, and television shows dealing with the West have seconded the historians, depicting a frontier that is anything but idyllic. Contemporary social problems in the West have been much-dramatized, as has regional intolerance toward those whose sexual preference, ethnicity, or politics veer from local norms. Even the most cursory survey of Netflix Westerns or the briefest glance at a recent Western Literature Association conference program offers an unambiguous message: the romanticized, Edenic myth of the West is under terminal attack.

5 And yet even as contemporary Western writers frankly, even enthusiastically, join the chorus dismantling exceptionalist claims about their own region, many of them are not quite ready to dismiss quite all of those claims, to concede that the land beyond the hundredth meridian was and is only a place just like any other. While admitting that the West is a complex and troubled region, not a place that has ever unilaterally fostered independence, strong families, economic success, or psychological and physical health, numerous contemporary Western writers tend to hold fast to one enduring regional stereotype: the exceptional, sacred power of the Western landscape. Using a sample of six Idaho writers who were born around the middle of the twentieth century and deserve to be more widely known, this essay will contend that such selective exceptionalism is not coincidental. Instead, I will argue that these contemporary Western writers pick and choose their claims according to their own preoccupations, imposing their generation's mind-set on the modern Western landscape as surely as earlier myth-makers did.

\section{Challenging the Archetypes of Western Individualism, Family Solidarity, and Success}

6 John Rember, Mary Clearman Blew, Marilynne Robinson, Janet Campbell Hale, William Vern Studebaker, and Ford Swetnam, all writers who have spent at least some of their lives in Idaho and have taken the state as their subject, are a varied group in many respects. They write in a variety of genres (memoir, fiction, poetry) and tones; they differ in gender, in ethnicity, in whether or not they are Western natives; they live in 
widely scattered parts of the vast state or currently outside the region. Some have been published by major presses, others only by regional or small presses. All, however, reflect the thinking of the decades in which they came to maturity, a 1960s and 70s "youth culture" ethos which has been well documented by numerous scholars, including Todd Gitlin and John C. McWilliams. These six writers project onto the West their concerns with personal alienation; they document "a culture of unhappiness and misery" caused by "social and political arrangements" (Rossinow 110) and by xenophobic suspicion and prejudice. They critique the tyranny and broken promises of conformist, authoritarian institutions; they question whether material success is inevitable for any virtuous American; they protest discrimination against women, the poor, and ethnic minorities.

One myth of the West with which they take particular issue is the romantic notion that Western communities are uniquely open, tolerant of individualism, and welcoming. Their narratives depict no cheerful community barn-raisings for newcomers; they offer no assertions that "the people out there were always ready to do anything they were called upon to do ... for anybody, no questions asked," as a cheerful unpublished pioneer community history contends of one Southeast Idaho hamlet (quoted in S. Swetnam 58). Instead, this generation of writers, with its first-hand experience of American intolerance for anti-Vietnam-War-protesters, for perceived communist sympathizers, and for civil-rights-advocates, dramatizes a contemporary West whose mind-set is extremely narrow. Mary Blew makes this case explicitly, "It is curious that westerners, so tolerant of the eccentric, the loner, or the crazed, so ready to make a folk hero out of a Butch Cassidy or a Long George Francis, can simultaneously harbor such dread of cultural difference" (All But the Waltz 89).

With humor at once affectionate and scathing, John Rember's memoir Traplines suggests that the remote community of Stanley, Idaho, in which Rember grew up in the 1950s and 60s, was every bit as closed and paranoid as any Westerner might imagine a conservative community "back east" to be. To the unprejudiced eye, Rember seems firmly grounded in place. His family lives close to Stanley on a ranch; as a child he attends school in the town; and as a recent high school graduate he lives temporarily in a cabin in town. Yet town residents insist that Rember is "not a local" (95). One woman even confides to a friend of Rember's many years later that the writer has been "misleading him" when he implied that he lived there. "Fifty years isn't long enough to be a local?" his friend asks incredulously (98). To further document the community's suspicious insularity, Traplines tells the story of a recent immigrant who is driven from town for trespassing on local prerogatives, though no one had ever cared about those customs before (101-05).

Traplines brings the pain of such rejection intimately home for readers by separating the adolescent character Rember from the narrator Rember, now a Harvard-educated college professor with a wider perspective. Distancing himself from the recent high school graduate, the latter smiles at the boy who affected bell-bottoms, fringed shirts and Dennis-Hopper-style mirrored sunglasses, believing himself extremely hip that summer of 1967 (113-26). At the same time, the memoir builds sympathy by dramatizing the hostility that boy brought on himself by his innocent eccentricity, hostility that drove him to desperate unhappiness, then violence (120-21). Things could have been worse, though, the narrator concedes, noting that several of the character's 
contemporaries "had been hospitalized after being mistaken for hippies by a group of men in cowboy clothes wielding baseball bats" (117-18).

Rember further emphasizes residents' intolerance and social claustrophobia by describing the taxonomy which residents of Stanley use to judge each other, not only outsiders and nonconformists: "the people who stay through the winter and the people who don't"; "the people who have jobs and the people on unemployment"; "the people who have been here long enough, and the people who haven't." "By the end of the winter," he says, "the divisions have gotten down to dietary habits and rumored sexual tastes and almost everyone in Stanley thinks everyone else is an outsider. It's a lonely town by March" (98). So much for the storied Western cooperative spirit, the storied Western tolerance for individual difference.

11 Several other writers in this group challenge a related myth of the West: its supposed potential to liberate feisty women from conventional limitations, a trope voiced both in classic Western texts (Elinore Pruitt Stewart's Letters of a Woman Homesteader) and in some contemporary work (Gretel Ehrlich's The Solace of Open Spaces). In her memoirs All But the Waltz, Balsamroot, and Imogene Welch, Pioneer Schoolteacher, in contrast, Mary Blew describes how conventionally-gendered assumptions have threatened to circumscribe five generations of rural Montana women. By juxtaposing journal entries, dramatized scenes in the past and present, and commentary, Blew emphasizes how her beloved Aunt Imogene, a central female character in all three works, is particularly victimized by her unmarried status. Although we know from reading Imogene's journal that she dreads the physical and emotional demands of teaching in an isolated one-room school, that career is the only one open to her in the early twentieth century. To assuage her loneliness, Imogene clings to her sister's family, living with them in the summers as a helpful but needy dependent. Such a role, Blew notes, has been an institution in the family, which has produced a spinster in every generation. "How useful she was!" Blew writes bitterly of another of such woman, using free indirect discourse to put words into the family's collective mouth. "All she asked was to live on the edges of her sisters' families, to love their children" (155).

Imogene seems headed for a similar life of self-abnegation in that "closed" and "straitened" place (Balsamroot 126) until a mowing accident nearly severs her foot and local school boards refuse to hire her. Then she faces a bleaker future as a woman economically as well as emotionally dependent. To avoid that fate, Imogene moves to Port Angeles, Washington, where the booming wartime economy has created a demand for teachers. Economically stable but intensely lonely, believing that she is lacking in fundamental human "security" (Balsamroot 208), Imogene sees the family she loves only in summers when she returns to Montana to help with the harvest and the children. Their critical voices continue to follow her even in Washington, though, undermining her attempts to think of herself as living an authentic life on her own: "I wonder what Imogene thinks she's going out there?' 'She bought a Buick?' '. . . What does a single woman want with her own house?'” (All But the Waltz 117).

Blew herself has been forced to take a stand against conventional gender roles, she reveals in an autobiographical narrative that alternates with and parallels Imogene's. Balsamroot and All But the Waltz describe how the narrator moves beyond basic teacher training to a college degree in English, then to a Ph.D., decisions which alienate her father. When she becomes pregnant as an undergraduate, her mother-in-law assumes 
"I guess this is the end of college for you!" (All But the Waltz 164), and even her college advisor reminds her that it is her husband's career that matters.

Although Blew goes on to build a distinguished career as a writer and university professor, she admits that after two failed marriages she has internalized the criticism. "I have never been worth a good goddamn at self-sacrifice," she confesses in Balsamroot, alluding to the familial model for single women. "Never. I'm the girl who got married at eighteen so I wouldn't have to go back to the ranch." She imagines a chorus throwing "the accusation after me through the years": "You're willing to trample on anybody to get where you're going . . Y You're hard as nails! You're selfish! Selfish!" (75). And literal voices continue to assail her. When Blew faces an anguished decision to put Imogene (who has come to live in the same town as dementia overtakes her) into a rest home, a nurse asks, "Can't you quit your job?", invoking the self-sacrifice model of true womanhood (63).

Yet even the most self-sacrificing Western women in Blew's narratives do not find true happiness. Blew portrays her mother, a ranchwife with a husband, children, and a house, as deeply lonely. One grandmother must economically fend for herself and her daughters after he husband loses their homestead and goes mad. The other, widowed early, spends many years as a dependent in her son's family; though she has a "boyfriend," she maintains emotional distance from him. Thus, it is virtually all women, married or single, who "skirt the edges, who prefer to keep their dread a secret" (Balsamroot 192) in Blew's West.

Marilynne Robinson's novel, Housekeeping, a PEN/Hemmingway award winner, also paints a complicated, vexed portrait of women's lives in the West. Like Blew's female characters, most of the women in Robinson's Northern Idaho town of Fingerbone have absorbed the belief that creating domestic order is the appropriate role for women, that not to devote oneself to this task is irresponsible and/or dangerous. The narrator Ruth's grandmother is among these domestic paragons, keeping the preternaturally neat house in which her orphaned granddaughters come to live. "Her bread was tender and her jelly was tart, she made cookies and applesauce," Ruth remembers, noting the roses in vases, the starched sheets, and the "turned back bedclothes" (11-12, 24-25). That standard is also maintained by the sheriff's wife who makes "the world's finest" apple pie (206); by the women horrified by the disorder in which the girls live after their grandmother dies and their Aunt Sylvie assumes charge of them; and by the woman whom Ruth imagines living in the house in later years, pruning the apple trees, planting flowers, and reestablishing "high and stiff" doilies, "a bright pantry curtain," and "a smell of starch whenever we might wander in the door" (216).

Thanks to the novel's scrambled chronology and its brooding descriptive passages, full of dark portents, however, it is clear from the start that such determined attempts to structure human life will not ultimately keep entropy at bay. Ruth's grandfather has died in a catastrophic train accident; her mother commits suicide. Flood waters engulf houses in the town, floating them off of their foundations; snow threatens to collapse roofs every winter. Transients visit the town, testifying to the fragility of domestic security. Recognizing this truth, Sylvie opens her arms to domestic chaos, refusing to pretend. Sylvie prefers cold snack food from cans to home-made staples; she keeps cats who leave bird parts scattered about. Soon, she stops cleaning entirely, leaving a curtain half-burned from birthday candles hanging in the main room. Sylvie does not 
protest when the girls cut school to wander in the woods or stay out overnight; indeed, she encourages such behavior. She herself, the narrator reveals, has been a transient.

Ruth's sister Lucille, a girl "of the common persuasion" (93), resists the strange disorder of Sylvie's life. She decries the house's chaos and demands meat and vegetables (102); she cultivates her ability to "look the way one was supposed to look"; she wears curlers and begins associating with "sleek and well-tended girls" (103). Soon Lucille decamps, going to live with a home economics teacher, and, as Ruth imagines her, living a determinedly conventional, orderly life.

Ruth is threatened with such a future, too, when the women of Fingerbone appoint themselves guardians of strict conventionality and seek to place her in foster care. They pump Ruth for evidence; they visit with casseroles to inspect the house. When one of them prompts her husband, the sheriff, to direct intervention, Sylvie commits an extreme act of domestic entropy, burning the house and resuming transient life with Ruth. But even these women, Robinson suggests through the picture of a Lucille haunted by the past that Ruth paints at the novel's end, cannot escape a sense of isolation, and, sooner or later, the dissolution of all they hold dear. Housekeeping ultimately suggests that the West is not a charmed place, that no one, wherever they live, can ever be sure of lasting security in a world which is itself essentially transient.

Janet Campbell Hale's novel The Jailing of Cecelia Capture contains another unconventional Western woman protagonist trammeled by gender assumptions, but in this case her troubles are compounded by ethnicity and class, and they directly question the fabled solidarity of the Western family, especially the Native American family, as well the myth of women's relative freedom in the West. As a teenage unwed mother in San Francisco in the 1960s, Cecelia, a member of the Coeur d'Alene tribe, is treated with little respect. Her caseworker calls her "absurd" to think of going to college to study an academic subject, saying, "you probably couldn't even complete a vocational program, anyway" (123). A man whose marriage proposal she rejects calls her "a nobody" (119). Her white husband condescends to her and abuses her during their violent fights. Although she is an excellent student at a top law school, he recommends a more "realistic career goal, such as becoming a social worker or a teacher of young children" (164). When she insists on returning to school from their Spokane home, he stops making love to her. In her absence, he beats her son and threatens the boy with reform school after a small offense (129).

21 Once again, though, it is the women in Cecelia's life that are most threatened by her bid for self-actualization, although their lives have demonstrated that domesticity is no guarantee of fulfillment. Cecelia's mother, an arthritic and bitter mixed-breed woman, inflects horrible abuse during Cecelia's childhood, calling her dirty, lazy, and ugly, mocking her for believing that she comes from Indian aristocracy. She also offers an ultimate insult for women echoed in Blew's work: "selfish" (84).

In Hale's subsequent memoir Bloodlines: Odyssey of a Native Daughter, she reveals that The Jailing of Cecelia Capture draws on a history of real-life abuse. When she was seven, she notes, her mother handed her a suitcase of clothes, saying, "get the hell out of here.... You're not pretty. You're not anything... People will instinctively know what an evil thing you are" (60-61). One summer the teenaged Hale was forced to live in a windowless shack in extreme heat, never allowed to enter her sister's air-conditioned house where the rest of the family was staying. As Bloodlines's narrator explores her own formative years, searching for answers to this maltreatment, she juxtaposes the 
distant past of her parents' and ancestors' youth with the era of her upbringing and her adult life and eventually realizes that the causes are deep-seated. Her mother also suffered abuse as a child and as a bride, she learns; her sisters are struggling with poverty; her forebears were marginalized and brutalized. Still, she cannot discount the abuse's lasting effect on her, and she imagines herself warning Indian schoolchildren about families that will "tear you down ... tell you you are a defective person. You could end up brokenhearted and brokenspirited" (xxi).

Another writer who frankly depicts family dysfunction in the twentieth century West is William Vern Studebaker. In his work, as in Hale's, Robinson's, and Blew's, we are much closer to 1960s-style cynicism about the conventional nuclear family than we are to Little-House-on-the Prairie-style archetypes.

As Studebaker's memoir, Short of a Good Promise, depicts his family's three-generation history in Idaho, it directly questions both the myth of frontier bootstrap success and the myth of the inevitably nurturing Western family. Drawn initially by the promise of early twentieth-century Carey-Act irrigation land in Southern Idaho, Studebaker's grandparents immediately encounter problems, discovering that they have been misled, that their land is "mostly blown sand." They are not alone, "surrounded by anxious families waiting for enough water for their crops and an occasional bath." "In two years," Studebaker writes of his paternal grandfather, "Granddad cleared his forty acres and sowed it in alfalfa and wheat. Within two months, it was all dead. The alfalfa had sprouted and stooled out, but the wind cut through the field, carving around the plants ... the roots could not hold" (49). Like most of their neighbors, they are forced to move to another part of the state (15). One grandfather does establish a paying ranch near Salmon, Idaho, but the other, wanting ready money, runs a home for indigent elderly populated by former miners and Dust Bowl refugees, none of whom has been able to succeed in this alleged "Promised Land" (19).

Despite its own hard-won economic stability, Studebaker's immediate family fractures emotionally. One of Studebaker's grandfathers, the book frankly reveals, is a womanizer, and his wife (raped in the Midwest before she immigrated as a mail-order bride) never forgives him (35). Her life after they separation is deeply troubled: she becomes so fat that she must be weighed at a grain elevator, and she teaches her grandson that "the only antidote for the incessantly jilted is revenge" (42). After her husband is killed in a car wreck with several of his mistresses, her revenge is to bury him alone (44). The other grandfather's eyes "flicked frustration, meanness"; he is so hard on his sons that both flee home-one never to return (53-54). Taking on the persona of his own father, in the interpolated poem "Wind Sickness" Studebaker imagines a hereditary family misery reminiscent of Hale's:

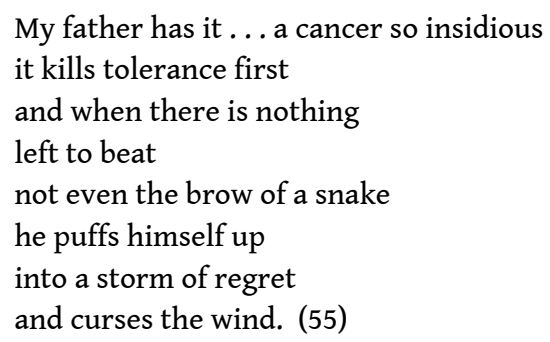

Eventually that grandfather becomes so deranged (he carries a bullwhip which he uses with abandon, even on his grandson) that he is committed to the state mental hospital, a move that "took its toll on family relations" (114-15). In other family sorrows, an aunt 
and uncle divorce, and the uncle, living alone in Oregon, commits suicide and is not missed by anyone for a long time (120). "If example teaches," Studebaker concludes of his family, "I have learned that there are pains in this life. Some are the result of injury. Some are the substance of life itself. But none are greater than the disappointments caused by loved ones" (42).

Unlike the writers just discussed, Ford Swetnam came to Idaho as an adult and so does not write first-hand of multiple Western generations, but the poems which he produced during his thirty-year life in the state give a keen and sympathetic attention to Westerners who have come up "short of a good promise" both in economic and psychological terms. One of the most vividly troubled Western families in his work appears in the poem "Flannery O'Connor Fire." The poet, who is fighting a housefire with his volunteer department, overhears a sheriff reveal that an oldest son just banished for misbehavior "came back with unknown accelerants," stuffed rags around the doors, and attempted to murder his kin. "As many fuses led to this house / As hoses now lead," Swetnam reflects (Ghostholders Know 24-25).

Other characters in Swetnam's poems are crippled by vices, like the methamphetamine-addicted narrator of the ballad "Lemon Creek Prison, Juneau" who "stood up to weakness" and turned his back on his wife and baby to run with a crowd of desperate "outlaws" (Ghostholders Know 30-31). Others are caught psychologically in "a basin / Not even water can escape," victims of their pasts, like the bitter barfly Vietnam veterans in "301" (67-75). Worst of all, like miserable characters in the books discussed previously, many are "in a damn fair way / To pass [grief] on" (75), including the troubled central character in "Ghostholders Know" who commits suicide with a rifle, leaving his daughter to carry his ashes to his gravesite

Up the hill, leaning to one side

To balance the weight

of the package in the bucket

And whatever weight that package

Is passing on to her (9)

Thus, all six of these writers, members of a generation whose motto was "question everything," take exception with myth of the West as immune to larger human misery, as a place where success and self-actualization are inevitable if one just wants them badly enough. Economic failure, stultifying conventional thinking, abuse, intolerance, and alienation are all realities of their Wests; Westerners face the same existential questions as anyone else. These may be Western writers using Western settings, but the ultimate themes of their work are archetypal, reflecting the concerns of a generation which actively distrusted pacifying received truths, a generation which insisted that human suffering was not to be ignored.

\section{Endorsing the Archetype of a Transcendent Western Landscape}

And yet, as suggested at the beginning of this essay, all six become extremely traditional, even mythic when they write about the Western landscape, sounding more like Cooper, Emerson, Thoreau, or Wordsworth than like cynical modernists. I would argue that in this concordance with exceptionalism, no less than in their critiques of other claims about the West, they are aligning themselves with generational values. 
Within these writers' adolescence and young adulthood, after all, the conservation movement took on renewed life, moving to the forefront of public concerns, thanks to literature which voiced concerns about environmental pollution (like Rachel Carson's Silent Spring), to the politicization of the Sierra Club under radical director David Brower in the 1950s and 60s, and to the rise of militant environmentalism championed by groups like Earth First. The works of early conservation writers including John Muir, Bob Marshall, and Aldo Leopold were reprinted, used in college classes, and widely read. In 1964 conservationist efforts were rewarded with the passage of the Federal Wilderness Act, which set aside 9.1 million acres from Western national forests, forbidding development of any kind. Over the next decade-and-a-half, fifteen million acres in the lower 48 and 56 million acres in Alaska were added to that total (Athearn 190-215). Contemporary creative writers who insisted on the necessity of connection with nature came to national prominence, including Carlos Castaneda, Edward Abbey, Annie Dillard, Ann Zwinger, and Barry Lopez. In the 1970s, the field of ecocriticism was born in literary studies.

31 In keeping with the concerns of their generation, these six Idaho writers also emphasize the salutary effects of landscape, insisting in particular on the power of Western landscape. Their works demonstrate, for one thing, that wilderness can bring psychological renewal to troubled humans, a position explicitly argued by Robert Marshall (for whom Montana's Bob Marshall Wilderness is named) in 1930. "It is only the possibility of convalescing in the wilderness which saves [modern humans] from being destroyed by the terrible neural tension of modern existence," Marshall wrote, contending that wilderness opened humans' minds, bringing not only solace and happiness but innovative ideas stimulated by "an objectivity and perspective seldom possible in the distracting propinquity of one's fellow men" ("The Problem of the Wilderness" 143).

Traplines implicitly seconds such contentions, demonstrating wild lands' potential to heal, comfort, and inspire. As a young man, the narrator escapes his stultifying human environment in Stanley and his mundane work as a ranger to read books for college at an isolated spot each afternoon, "free of responsibility, free of clothes, free of any twinges of conscience about not working," lying "on the rough warm sand until the shadows of the high cliffs above the lake touched the water." In that deeply peaceful spot, "The words that I read went through my head and became the world" (150-51). In middle age, he climbs a hill near his house daily, reveling on winter ski ascents that suggest that "I can fly," that he is still possessed of free will (194). Traplines suggests that the Sawtooth Valley also nurtures John Rember as a writer, enabling him to look up from his desk to "see the cold stone towers of Mount Heyburn, their ragged edges smoothed by thick drifts of snow" or take a head-clearing breaks "to wander the fence lines, or [sit] on the melted-off riverbank to watch the flyovers of returning geese, or [ski] the hill behind the house" (4). The back-country, he notes, can even alleviate the effects of aging, as when a person jumps off rocks into a river and gets "out of the water substantially younger than when [he] jumped into it" (84). Trips to the mountains, he reveals, have taught him that healing is possible (192).

Blew also invokes the restorative capacity of wild Western landscape, beginning All But the Waltz, as Rember begins Traplines, with a vivid invocation of place. Even a person who has wandered far from home, she suggests, a person who understands just how variable memory is and how insubstantial a sense of self can be, can find emotional 
grounding in a particular landscape. Although she has turned her back on the country of her childhood to "breathe [her] own air" (145), revisiting it brings automatic, visceral connection: "In this dome of sky and river and undeflected sunlight, in this illusion of timelessness, I can almost feel my body, blood, and breath in the broken line of the bluffs and the pervasive scent of ripening sweet clover and dust" (7). Her family, she suggests, is as difficult and isolated as the Montana plains, but also as stubbornly strong, and she has imbibed this trait (17).

When Blew flees across the Lolo Pass into Idaho to escape both her family and her troubled marriage, she is at first anguished ("Why did I have to make a choice between going home and being slowly suffocated, and having to break with home to breathe my own air?" she asks in Balsamroot [145]). She soon realizes, though, that this new country will play a crucial role in helping her "try for another narrative" (Balsamroot 149). In particular, the Clearwater and Snake Rivers help Blew construct a story that makes her new independent life meaningful. She identifies with the Nez Perce, who were displaced from this home country, and she discovers faith in continuity when the rivers are drawn down to reveal their original channels. At the end of the book, on horseback with her daughter, she senses "the fragmented parts of my life ... settling together ... where the light falls in sharp edges and the irrevocable crags and bare grass plummet seven hundred feet down to the Snake" (202). Though the immediate landscape is filled with tawdry evidence of human presence-4-wheel drive ruts, broken glass, condomsthe feel of the horse and the open land reassures her that "I am myself" (211). Being "bone-deep in landscape," in Blew's memoirs, offers exactly the kind of non-rational but certain consolation that Marshall asserted.

Janet Campbell Hale expresses an especially deep psychic connection with her tribal homeland in Northern Idaho. "There is no place on earth more beautiful than Coeur d'Alene country," she writes unequivocally (Bloodlines xviii). "Just think," she tells elementary school reservation children, "how long our tribe has existed right here in this very place," speaking of their connection "to the land and to each other" (xix). Using metaphors of physical longing and relief, she describes the effect of her homeland on her soul: "I have hungered for the sight, the presence, of snowcapped mountains ... The air is so fresh-smelling, too, easy to breathe, a pleasure to breathe" (169-70). In this home landscape, she insists, "I'm not afraid" (182-87).

All Western land which has seen tribal history enacted, indeed, is "sacred" for Hale, for it draws her closer to the ancestors who once inhabited it, like the grandmother who was drawn along with Chief Joseph's flight:

I was with those people, was part of them. I felt the presence of my grandmother there as though two parts of her met each other that day: the ghost of the girl she was in 1877 (and that part of her will remain forever in that place) and the part of her that lives on in me, in inherited memories of her, in my blood and in my spirit. (Bloodlines 152-58)

Like her creator, Hale's fictional creation Cecelia Capture recognizes that maintaining ties to ancestral homelands is crucial. She acknowledges the pathos and squalor of urban Indians in California who reminisce fondly of their reservations but remain "sidewalk Indians" (112), and saves herself from suicide with the thought that "she wanted to be buried in northern Idaho in the little tribal cemetery near her dad and her two dead brothers and all the other Captures. Because that was what she was. Cecelia Capture. Cecelia Eagle Capture" (199). 

Western wild places to affect the psychology of human beings, but they go farther explicitly endowing such places with spiritual symbolism, even animate power. All three, indeed, might be termed ecospiritualists, writers who would agree with iconic conservationist John Muir that the monumental, untamed Western landscape offers "endless revelation" of powers beyond the human, though the exact nature of that revelation might remain "mysterious ... unreadable, immeasurable" (John of the Mountains 58, 88) land around Fingerbone as majestic but brooding and even ominous, a decidedly uncomforting reminder of the smallness of the individual human life. "One is always aware of the lake," Ruth notes, "or the deeps of the lake, the lightless, airless waters below" (9). The mountains, too, become animate and strange in their ruinous aspect, "like the remnants of a broken dam, or like the broken lip of an iron pot, just at a simmer, endlessly distilling water into light" (112). As suggested earlier in this essay, natural forces in Fingerbone continually invade and threaten human domestic arrangements. Critic John Gatta, indeed, has argued for explicit connections between landscape and spiritual archetypes in the novel's "pivotal but unobtrusive biblical allusions." He identifies the lake with primordial chaos and with Noah, and suggests that Ruth and Sylvie's bridge crossing at the work's end represents "a rite of passage intermingling sensations of birth, death, and baptism" (223).

If this is God's world, however, it is, as Gatta acknowledges, one that stays mysterious, "a holy and terrifying abyss" where even Ruth's concluding epiphany stays shadowy, and she is left to wonder whether she and Sylvie really encountered on the bridge "some sound too loud to be heard, some word so true we did not understand it, but merely felt it pour through our nerves like darkness or water" (215). In Housekeeping, the landscape offers no anthropocentric comfort, no clear assurance that human life has meaning.

William Studebaker and Ford Swetnam both insist, as Robinson does, on the otherness of the Western landscape, but their work comes to more comforting conclusions about its spiritual relationship to humans, echoing John Muir's pantheism, which one commentator has described as a quasi-theology that "revivifie[d] an archaic sense of the sacrality of all being" (Oelschlaeger 173). Echoing the Romantic idea of the sublime, Muir held that all aspects of the natural world not only were spiritually interconnected, but also possessed of their own animate spirits:

Plants are credited with but dim and uncertain sensation, and minerals with positively none at all. But why may not even a mineral arrangement of matter be endowed with sensation of a kind that we in our blind exclusive perfection can have no manner of communication with? (Thousand Mile Walk [145])

"Water does not seem to be under the domination of the ordinary," Muir wrote of Yosemite waterfalls, "but rather as if it were a living creature, full of strength of the mountains and their huge wild joy" (My First Summer 188).

Studebaker's poems, especially those in the volume celebrating the high desert of Southern Idaho and Nevada, Travelers in an Antique Land, directly endorse such an animate view of the natural world. In "The Space Closest to Our Bodies," Studebaker writes,

Imagine everything here moves 
(even the cactus will come close

to a sleeping man

and the beetle will tunnel

under the arch of his foot)

and a full half-moon

is enough light for gray things. (2)

In this stark landscape, stones "snor[e]" (14); "Plants lean for the sun / and roots find a way-and dreams" (6). Human beings wandering in this stark landscape are conflated with other creatures. "We sit like coyotes," Studebaker reflects (4), "snakes . . rattle / like the inside of your head" (14), "We are one of the animals / gathering food / keeping our eyes peeled" (43), and "like the moon we will change shape" (49).

Though several of the poems do suggest a creator-God responsible for all of this (especially "The Bruneau Desert," which begins "This is where God spent a day / roughframing the canyons" and suggests that He returns at night to "brood" [10]), Studebaker rarely voices a conventionally christian reading of nature as God's handiwork, instead evoking a mysterious indwelling lifeforce. Ultimately, what the poet longs for is not necessarily salvation, but a merging that leaves human incarnation behind:

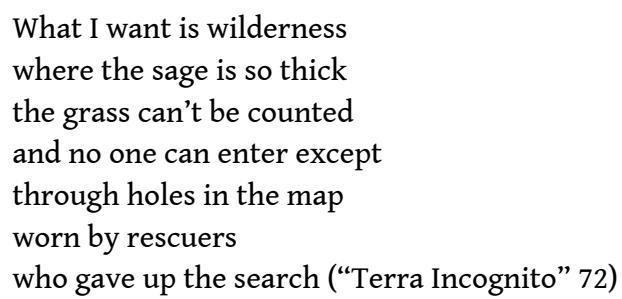

In 2008 , Studebaker himself eerily found such escape after he disappeared in a kayaking accident.

Swetnam's poetry, like Studebaker's, evokes the high desert as an animate landscape in which humans can hear nature, as Muir put it, "whispering, cooing in a language I never learned" (My First Summer in the Sierra 92). His early work describes fleeting moments when he loses his ego-self in nature ("Night Climb, Granite Creek," "Walking Home from Poetry Reading, Full Moon," "Cadillac to Neakhakani," [Ghostholders Know $14,37,87])$. But it is Swetnam's last poems, written as he was dying of cancer, that are most relevant to this analysis, for in them he directly posits a sacred presence tangible in wild places. In Offer the Cup to a Friend (unpaginated), his last complete book, he uses pre-Christian archetypes to describe Idaho's Arco Desert, a strange place broken by lava flows and rifts, which holds experimental nuclear reactor facilities above ground and a vast underground river below. In "Lost River Lascaux" he imagines underground caves where "the antelope drink the aquifer, / plutonium, sweet water, and all. / When they lean on the lava walls, / the dark rock drinks their shape / and shines." "You think they're not here?" he asks incredulously in "Where Will the Plutonium Go" of readers who might doubt the presence of "the old gods" in the desert, conjuring up a mountain buzzing and coyotes praying, enumerating strange wonders and "shrines" amid the apparent wasteground.

Though Swetnam's animate wilderness is no more overtly cozy with humankind than Studebaker's or Robinson's, this poet invests it with suggestions of regeneration, even rebirth that offer tentative hope for all creation. The Persephone figure in "She Really Likes to Go Down There" knows that after her passage underground with the Big Lost River she will "fall[] free into the light / at Thousand Springs, / clean as anyone / after 
a shower." The posthumously-published "Will the River Live Again?" asserts of the Columbia River system "Something will, and something will live in it." Citing the West's ongoing history of earthquake and eruption as evidence of cyclic revolution, Swetnam imagines an apocalyptic scouring when a new dam, forming at the site of the ancient Lake Missoula, finally breaks. The poem concludes, with millennial yearning,

Stand at Dry Falls.

When the wind is right

a mighty roar seems but suspended.

Tell me you hear it.

\section{Conclusion}

All six of these writers, thus, selectively endorse the exceptional, even sacral, power of Western landscape, even as they roundly debunk claims about the West's inevitably salutary effects on tolerance, family life, and success. This paper has argued that in both regards they are "writ[ing] the history of the past anew with reference to the conditions uppermost in [their] own time" as the young Frederick Jackson Turner claimed that "every age" did (18). The American West, their work conclusively demonstrates, continues even today to be a palimpsest, a slate on which many Wests, many American dreams, fears, and longings have been and may yet be written.

\section{BIBLIOGRAPHY}

The Mythic West in Twentieth-Century America. Lawrence: UP of Kansas, 1986.

Blew, Mary Clearman. All But the Waltz: A Memoir of Five Generations in the Life of a Montana Family. Norman: U of Oklahoma P, 1991.

---. Balsamroot. New York: Viking, 1994.

Braunstein, Peter, and Michael William Doyle, ed. Imagine Nation: The American Counterculture of the 1960s and 1970s. New York: Routledge, 2002.

Ehrlich, Gretel. The Solace of Open Spaces. New York: Penguin, 1985.

Gatta, John. Making Nature Sacred: Literature, Religion, and Environment in America from the Puritans to the Present. New York: Oxford UP, 2004.

Gitlin, Todd. The Sixties: Years of Hope, Days of Rage. New York: Bantam Books, 1987.

Hale, Janet Campbell. Bloodlines: Odyssey of a Native Daughter. Tucson: U of Arizona P, 1993.

--- The Jailing of Cecelia Capture. Albuquerque: U New Mexico P, 1985.

Limerick, Patricia Nelson. The Legacy of Conquest: The Unbroken Past of the American West. New York: Norton, 1987.

Marshall, Robert. “The Problem of Wilderness.” Scientific Monthly 30.2 (1930): 141-48.

McWilliams, John C. The 1960s Cultural Revolution. Westport, CT: Greenwood, 2000. 
Muir, John. John of the Mountains: The Unpublished Journals of John Muir. Ed. Linnie Marsh Wolfe. Madison: U of Wisconsin P, 1979.

-- - My First Summer in the Sierra. Boston: Houghton Mifflin, 1911.

--_. A Thousand Mile Walk to the Gulf. Boston: Houghton Mifflin, 1916.

Oelschlaeger, Max. The Idea of Wilderness: From Prehistory to the Age of Ecology. New Haven: Yale UP, 1991.

Rember, John. Traplines: Coming Home to Sawtooth Valley. New York: Vintage, 2003.

Robinson, Marilynne. Housekeeping. New York: Farrar, Straus and Giroux, 1980.

Rossinow, Doug. “'The Revolution is About Our Lives': The New Left's Counterculture.” Imagine Nation: The American Counterculture of the 1960's and 70's. Ed. Peter Braunstein and Michael William Doyle. New York: Routledge, 2002. 99-124.

Stegner, Wallace. "I Sing of America.” Holiday 56.2 (1975): 39, 49.

Stewart, Elinore Pruitt. Letters of a Woman Homesteader. 1914. Rpt. Lincoln: U of Nebraska P, 1961.

Studebaker, William Vern. Short of a Good Promise. Pullman, WA: Eastern Washington UP, 1999.

-—-. Travelers in an Antique Land. Moscow, ID: U of Idaho P, 1997.

Swetnam, Ford. Ghostholders Know. Pocatello, ID: Blue Scarab Press, 1999.

-_-. It's All to Go. Pocatello, ID: Blue Scarab Press, 2004.

---. Offer the Cup to a Friend. Boise, ID: Limberlost Press, 2002.

Swetnam, Susan. Lives of the Saints in Southeast Idaho: An Introduction to Mormon Pioneer Life Story Writing. Moscow, ID: U of Idaho P, 1990.

Turner, Frederick Jackson. “The Significance of History.” 1891. Rpt. in Rereading Frederick Jackson Turner: "The Significance of the Frontier in American History" and Other Essays. Ed. John Mack Faragher. New York: Henry Holt, 1994. 11-30.

Wilder, Laura Ingalls. Little House on the Prairie. New York: Harper, 1935.

Worster, Donald. Rivers of Empire: Water, Aridity, and the Growth of the American West. New York: Pantheon, 1985.

Wrobel, David M. The End of American Exceptionalism: Frontier Anxiety From the Old West to the New Deal. Lawrence: UP of Kansas, 1993.

---. Promised Lands: Promotion, Memory, and the Creation of the American West. Lawrence: UP of Kansas, 2002.

\section{ABSTRACTS}

This paper examines the work of six contemporary Idaho writers born around the middle of the twentieth century who challenge several persistent myths of the American West while firmly endorsing another. Across the boundaries of gender and genre, these writers debunk the notions that the West is a friendly, open place that values non-conformity (particularly selfdetermination in women); that the region inherently fosters strong families; and that the opportunities of the West all but assure success and happiness. On the other hand, their work does uniformly present an exceptionalist view of Western landscape, crediting it with the 
potential to nurture and inspire individuals in a quasi-mystic way, and even endowing that landscape with animate power. Such selective exceptionalism, the paper argues, can be traced to the concerns of their particular generation. Writers discussed are John Rember, Mary Clearman Blew, Marilynne Robinson, Janet Campbell Hale, William Vern Studebaker, and Ford Swetnam.

INDEX

Keywords: Abuse, Conservation, Economic Failure in the West, Ecospirituality, Exceptionalism, Family, Idaho Literature, Individualism, Landscape, Loneliness, Wilderness, Women in the West

\section{AUTHORS}

\section{SUSAN H. SWETNAM}

Idaho State University, USA 